\title{
PESAN DALAM PROGRAM KOTA KREATIF DAN SIKAP FOLLOWERS TERHADAP PENGEMBANGAN EKONOMI KREATIF
}

\author{
Adzkia Kirana Dipa, Hanny Hafiar, dan Anwar Sani \\ kiranairsyel@gmail.com, hannyhafiar@gmail.com \\ Universitas Padjadjaran, Jl. Raya Bandung Sumedang KM.21, Hegarmanah, Kec. Jatinangor, Kabupaten \\ Sumedang, Jawa Barat 45363, Indonesia.
}

Submitted: 21 April 2020 Revised: 5 April 2020 Accepted: 13 Mei 2020

\begin{abstract}
Abstrak
Program Kota Kreatif adalah program yang diikuti oleh kota-kota terpilih di Indonesia untuk mendukung pengembangan ekonomi kreatif. Penelitian ini bertujuan mengetahui sejauhmana hubunga antara pesan dalam program Kota Kreatif pada akun Instagram @kominfopadangpanjang dengan sikap followers terhadap pengembangan ekonomi kreatif. Penelitian ini menggunakan teori AISAS dari Dentsu Ink dengan metode korelasional serta teknik analisis data deskriptif dan inferensial. Jumlah sampel pada penelitian ini adalah sebanyak 93 orang ditentukan melalui teknik simple random sampling. Pengumpulan data dilakukan dengan cara penyebarkan angket, wawancara, dan studi pustaka. Hasil penelitian ini ialah terdapat hubungan yang kuat antara pesan pada program Kota Kreatif dengan sikap followers terhadap pengembangan ekonomi kreatif. Simpulan dari penelitian ini terdapat hubungan yang kuat antara pesan program Kota Kreatif dengan komponen sikap attention, dan hubungan yang cukup berarti antara pesan program Kota Kreatif dengan kompnen sikap interest, search, action dan share. Berdasarkan simpulan tersebut, peneliti menyarankan agar sasaran khalayak lebih spesifik pada wanita usia muda dan mahasiswa. Kemudian perbaikan pada kelengkapan pesan, kualitas visual serta format pesan berbentuk video.
\end{abstract}

Kata kunci: Ekonomi Kreatif, Media Sosial, Program Kota Kreatif, Perubahan Sikap Teori AISAS.

\section{MESSAGE IN KOTA KREATIF PROGRAM IN INSTAGRAM ACCOUNTS AND FOLLOWERS ATTITUDES TOWARD ECONOMY CREATIVE DEVELOPMENT}

\begin{abstract}
Kota Kreatif Program is a program that is followed by selected cities in Indonesia to support the development of the creative economyThe aim of this study is to acknowledge the correlation between the message in the Message in the Program Kota Kreatif on instagram @kominfopadangpanjang account with behavior of followers toward economy creative develpoment. This study used AISAS and correlation method with descriptive and inferential statistical analysis. The amount of samples was 93 people which was obtained by simple random sampling technique. The data was obtained by questionnaire, interview, and literature review. The result of this study was that there was strong correlation between Message in the Program Kota Kreatif with behavior of followers toward economy creative develpoment. The conclusions of this study was that there was strong relationship between the campaign message Program Kota Kreatif with attentio aspect, and a significant relationship between the campaign message Program Kota Kreatif with interest aspects, search aspect, action aspect and share aspects. Based on these conclusions, the researcher suggests that the target is young women and college student. with complete information message and improvement on visualization quality, and message on video format.
\end{abstract}

Keywords: Creative Economy, Social Media, Kota Kreatif Program, Change of behaviour AISAS Theory 


\section{PENDAHULUAN}

Teknologi informasi dan komunikasi adalah segala sesuatu yang mendukung untuk merekam, menyimpan, memproses, mendapat lagi, memancar atau mengantarkan, dan menerima informasi (Munir, 2009). Salah satu bentuk kemajuan teknologi dalam bidang informasi adalah adanya New Media. Dewasa ini, banyaknya jenis media yang mendukung penyebaran informasi membuat manusia lebih mudah untuk memperoleh informasi tersebut. Salah satunya adalah menggunakan media jejaring sosial sebagai sumber informasi. Pada riset terdahulu mengenai new media didapatkan hasil bahwa pada saat ini media lebih dari mekanisme sederhana untuk menyebarluaskan informasi, maka media merupakan pemeran utama ideologi dan sikap, maka Media sangat potensial untuk menyebarkan hal tersebut melalui new media.

Jejaring sosial adalah alat bantu dalam menyampaikan informasi dari seseorang kepada seseorang atau kelompok orang untuk mencapai tujuan individu atau kelompok (Sukmi, 2018). Jejaring sosial dapat dikatakan sebagai media atau fasilitator untuk menyebarluaskan informasi kepada individu atau kelompok untuk mencapai tujuan tertentuSebagai perangkat teknologi, media komunikasi memberikan beberapa efek yang tidak dapat dihindari yang diantaranya meliputi aspek kognitif, aspek afektif dan aspek behavioral (Nida, 2014). Efek kognitif terjadi bila ada perubahan pada apa yang diketahui, dipahami, atau dipersepi khalayak.
Penelitian sejenis terdahulu yang menyatakan dampak dari internet communication sangatlah besar untuk membentuk sikap dari khalayak, Potensi penyampaian pesan melalui sosial media tentunya besar untuk berhasil (Prasetyo \& Rachmawati, 2016). Seakan diperkuat oleh penelitian sebelumnya mengenai media sosial, komunikasi interpersonal dan komunikasi massa melebur menjadi satu. Saat seseorang mengunggah sesuatu kemudian ditanggapi pihak lain, lalu terjadi interaksi, maka komunikasi interper- sonal terjadi (Watie, 2011). Banyaknya pengguna jejaring sosial di Indonesia dibuktikan dari data yang dirilis oleh Asosiasi Penyelenggara Jasa Internet Indonesia (APJII) pada tahun-2019 yang menyatakan bahwa pengguna jejaring sosial di Indonesia mencapai 171 juta pengguna (APJII, 2019). Angka yang tidak mengherankan, mengingat Indonesia merupakan salah satu negara paling aktif di media sosial.

Pesatnya perkembangan Instagram di Indonesia, membuat banyaknya akunakun yang tidak mengatasnamakan individu saja, bahkan perusahaan dan instansi pemerintah juga menggunakan Instagram untuk memberikan informasi kepada masyarakat. Merujuk kepada penelitian sejenis yang pernah dilakukan mengenai sosial media yang hasilnya menyebutkan bahwa kampanye atau penyampaian pesan secara online melalui media sosial kepada sasaran berhasil untuk mempengaruhi sikap khalayak (Putri \& Ali, 2017). Pemerintah menggunakan akun jejaring sosial khususnya instagram untuk menjalankan E-Government dalam memanfaatkan teknologi informasi dan 
mengikuti perkembangan penggunaan internet di Indonesia saat ini. Pada riset tentang program Kota Kreatif dinyatakan bahwa pada saat ini pemerintah menyadari bahwa masa depan dunia bergeser dan bertumpu pada kekuatan ekonomi berbasis kreatif dan ide, maka masyarakat kota harus diarahkan kepada sektor ekonomi kreatif untuk menjadikan ekonomi kreatif yang mampu bersaing dalam skala nasional dan internasional (Manisya, 2019). Termasuk Pemerintah Kota Padang Panjang, namun peneliti menemukan masih kurangnya partisipasi masyarakat mengenai perkembangan ekonomi kreatif. Untuk itu perlu melihat seberapa besar hubungan pesan persuasi yang diberikan dengan sikap masyarakat. Sebagai acuan dalam melihat bagaimana pesan persuasi program Kota Kreatif yang dilihat oleh followers akun Instagram @kominfopadangpanjang yang melahirkan sikap terhadap pengembangan ekonomi kreatif yang dapat dilihat berdasarkan teori yang dikembangkan oleh Dentsu Inc sebagai The Most Innovative Advertising Agency di Jepang pada tahun2008 yaitu Teori AISAS (Attention, Interest, Search, Action dan Share). Teori ini mempunyai indikator untuk mengukur sikap khalayak pada sosial media. Teori ini juga menyatakan bahwa khalayak akan melakukan penerimaan yang mendalam, aktif serta melakukan pencarian informasi sendiri sebagai akibat dari sebuah pesan persuasi yang disampaikan.

\section{METODE PENELITIAN}

Pendekatan yang akan digunakan dalam penelitian ini adalah metode kuantitatif. Meotde kuantitatif adalah metode yang digunakan untuk meneliti pada populasi atau sampel tertentu, pengumpulan data menggunakan instrumen penelitian, analisis data yang bersifat kuantitatif atau statistik, dengan tujuan menguji hipotesis yang telah ditetapkan (Sugiyono, 2012). Sedangkan jenis penelitian yang digunakan adalah penelitian korelasional, di mana penelitian ini bertujuan untuk melihat sejauh mana hubungan antara dua variabel atau lebih. Jika yang dilihat adalah hubungan atau korelasi dua variabel disebut korelasi sederhana (simple correlation), jika lebih maka menggunakan korelasi ganda (multiple correlation) (Rakhmat, 2009).

Teknik yang digunakan pada penelitian ini adalah probability sampling dengan jenis simple random sampling. Probability sampling adalah teknik pengambilan sampel yang berpeluang sama bagi setiap anggota populasi untuk berkesempatan dipilih menjadi anggota sample. Simple random sampling adalah pengambilan anggota sampel dari populasi secara acak tanpa memperhatikan strata yang ada dalam penelitian (Sugiyono, 2012). Populasi penelitian ini adalah seluruh followers yang berjumlah 3441 orang dengan jumlah sampel 96 orang, kuesioner dibagikan secara online. Penelitian korelasioanl ini berkaitan dengan penggunaan metode korelasional untuk meneliti hubungan antara pesan pada Program Kota Kreatif dalam akun Instagram@kominfopadangpanjang sebagai penyedia konten dan penyampai konten (variabel $\mathrm{X}$ ) terhadap perubahan sikap followers mengenai pengembangan ekonomi kreatif (variabel Y), berdasarkan teori AISAS.

\section{HASIL DAN PEMBAHASAN}

Hasil analisis statistik inferensial merupakan derajat hubungan antar 
variable yang dihitung dengan menggunakan korelasi Rank Spearman, karena skala data yang digunakan yaitu ordinal. Dalam analisis statistik inferensial dilakukan pemberian skor terhadap data yang telah dihasilkan dari masing-masing pernyataan dalam angket penelitian dan dilakukan penjumlahan skor dalam setiap variabelnya.

Berdasarkan kriteri Guildford, koefisien korelasi sebesar 0,770 di antara kriteria $>0,70-0,90$ menunjukan hubungan yang kuat antara pesan pada program Kota Kreatif dalam akun Instagram @kominfopadangpanjang dengan sikap followers terhadap pengembangan ekonomi kreatif. Hasil uji signifikansi diperoleh nilai t hitung sebesar 14,950 dan nilai t tabel dengan $\alpha=5 \%$ dan $\mathrm{dk}$ (derajat kebebasan $)=n-2=91$ adalah sebesar 1,986 maka dapat dilihat bahwa t hitung $(14,950)>\mathrm{t}$ tabel $(1,986)$ sehingga Ho ditolak. Dengan demikian dapat diambil kesimpulan bahwa program Kota Kreatif dalam akun Instagram @kominfopadangpanjang akan mampu membentuk sikap positif bagi para followers terhadap pengembangan ekonomi kreatif. Hal ini sejalan dengan hasil penelitian yang menyebutkan bahwa penyampaian pesan di media sosial memiliki peran signifikan dalam memunculkan sikap yang kontinu atau berhubungan baik dengan keseluruhan variabel sikap khalayak (Putri \& Ali, 2017).

Teori yang digunakan dalam penelitian ini adalah Teori AISAS oleh Dentsu Inc. Dentsu mengemukakan sebuah teori komunikasi yang didapat dari perkembangan teknologi, yang diberi nama AISAS maka akan dilihat proses transformasi psikologis dalam menerima sebuah pesan persuasi yang akan mengarahkan khalayak untuk melakukan sikap yaitu Attention, Interest, Search, Action, dan Share dimana setiap komponen pengetahuan menentukan high involvement dan low involvement khalayak saat menerima pesan tersebut. Teori ini dipilih berdasarkan program Kota Kreatif yang diadakan oleh Dinas Komunikasi dan Informatika Kota Padang Panjang untuk memberikan edukasi kepada masyakarat mengenai pentingnya pengembangan ekonomi kreatif. Tujuan dilaksanakannya program ini untuk mendorong setiap orang melakukan pengembangan ekonomi kreatif agar potensi Kota Padang Panjang dapat meningkatkan kesejahteraan masyarakat. Hubungan yang kuat antara pesan pada program Kota Kreatif menunjukkan bahwa context yang merupakan urgensi dan relevansi pesan dan content yang merupakan keahlian tokoh, daya tarik tokoh, audio, dan visual dalam pesan program Kota Kreatif dapat mengubah sikap followers terhadap pengembangan ekonomi kreatif.

Sewaktu individu dihadapkan pada pesan maka ia akan memikirkan pesan itu, memikirkan argumentasi apa yang terkandung di dalamnya dan argumentasi apa yang tidak. Pemikiran-pemikiran inilah yang membawa kepada penerimaan atau penolakan pesan yang disampaikan, bukan pesan itu sendiri. Pada penelitian terdahulu ditemukan bahwa saat ini, Pengguna media berusaha untuk mencari sumber yang paling baik di dalam usaha memenuhi kebutuhannya (Burhanuddin, 2015) . Akan tetapi pemikiran yang dilakukan bukanlah pemikiran inidividu sewaktu berpikir menghadapi persoalan yang berat. Sejauh mana kita akan berpikir tergantung pada seberapa penting dan 
seberapa relevannya pesan tersebut bagi kita. Kalau memang pesan yang disampaikan itu sangat penting dan relevan bagi kita, barulah kita akan berpikir secara lebih hati-hati dan mendalam. (Sugiyama, 2011)

Berdasarkan content pesan, ini dimungkinkan apabila kunci persuasi (persuasion cues) merupakan informasi yang ada hubungannya dengan keahlian atau status pelaku persuasi atau berupa penyajian suatu komunikasi dua arah yang tampak lebih seimbang dan tidak memihak (Sugiyama, 2011). Content juga cenderung dilalui apabila target atau subjek persuasi dalam keadaan terpecah konsentrasinya sehingga tidak dapat menaruh perhatian penuh dan tidak dapat melakukan analisis mendalam terhadap isi pesan yang disampaikan. Menurut tabel di bawah ini:

\section{Tabel 1. Hubungan antara pesan dalam Program Kota Kreatif pada akun @kominfopadangpanjang dengan Sikap terhadap Pengembangan Ekonomi} Kreatif

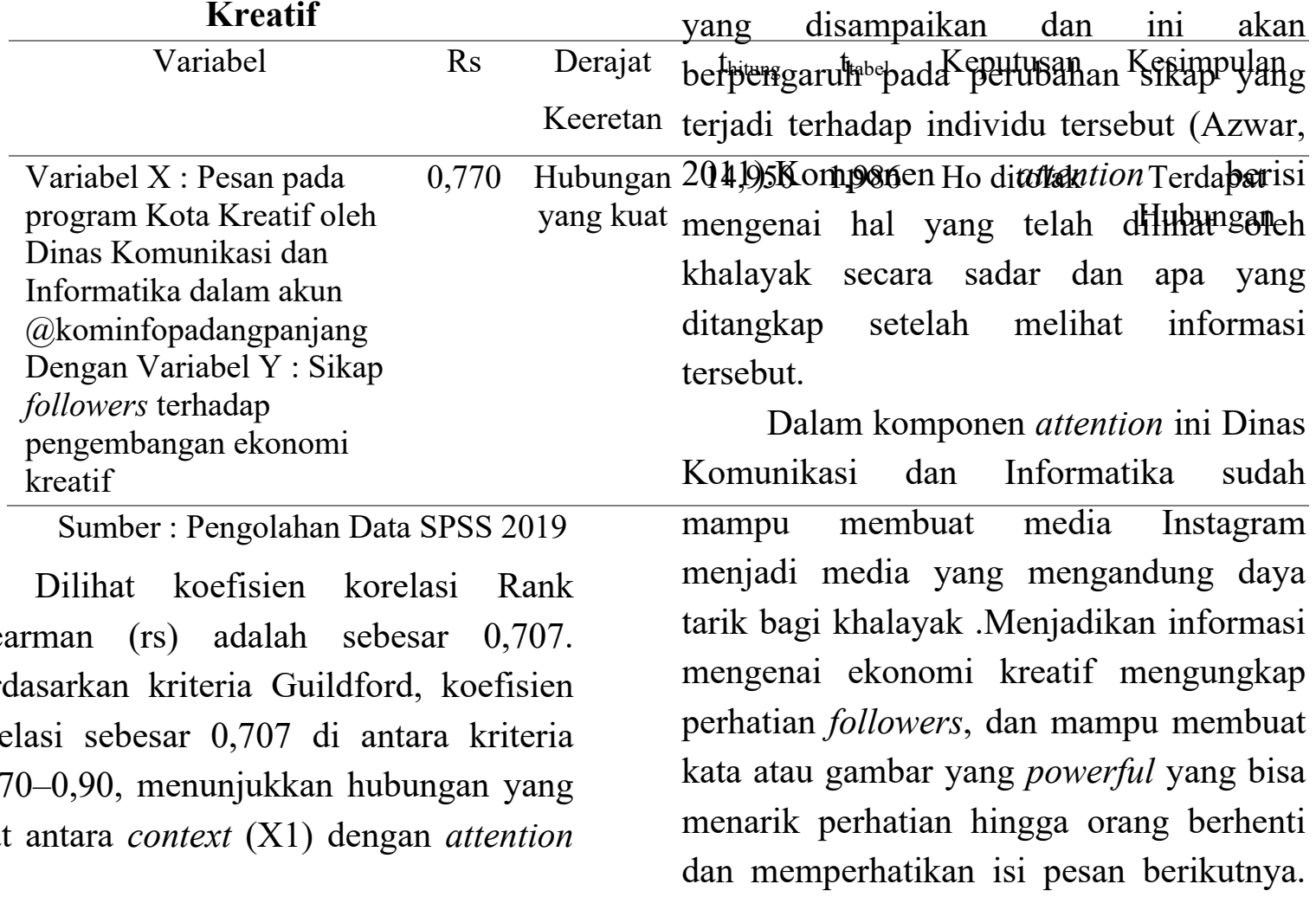

(Y1). Hasil uji signifikansi diperoleh nilai t hitung sebesar 13,487 dan nilai t tabel dengan $\alpha=5 \%$ dan $\mathrm{dk}$ (derajat kebebasan) $=\mathrm{n}-2=91$ adalah sebesar 1,986 maka dapat dilihat bahwa $\mathrm{t}$ hitung $(13,487)>\mathrm{t}$ tabel $(1,986)$ sehingga Ho ditolak.

Dengan demikian dapat diambil keputusan bahwa terdapat hubungan yang signifikan antara context (X1) dengan attention (Y1). Hal ini menunjukan bahwa context berupa urgensi dan relevansi pesan dari program Kota Kreatif berkolasi dengan aspek attention para followers terhadap pengembangan ekonomi kreatif. Maka semakin penting dan relevan suatu pesan, semakin baik pula aspek attention yang tumbuh pada sikap para followers terhadap pengembangan ekonomi kreatif.

Jika pesan yang disampaikan dianggap penting dan relevan, artinya pesan tersebut berkaitan dengan nilai dasar dalam diri kita atau dikarenakan pesan itu berkaitan dengan akibat yang tidak sepele, maka individu akan memikirkan secara hati-hati dan mendalam terhadap pesan yang disampaikan dan ini akan

.


Kotler \& Amstrong (2001) mengemukakan bahwasanya isi pesan (context) untuk memunculkan daya tarik (attention) haruslah mempunyai tiga sifat: (1) Harus bermakna (meaningful), menunjukkan manfaat yang membuat pesan lebih diinginkan atau lebih menarik bagi khalayak, (2) Pesan harus dapat dipercaya (believable), (3) Distinctive, bahwa pesan persuasi lebih baik dibanding pesaing. Jika mayoritas responden menjawab setuju memiliki komponen sikap attention, maka context pesan persuasi yang diberikan sudah memenuhi tiga sifat diatas. Hal ini juga sesuai dengan hasil penelitian sejenis bahwa penyampaian pesan persuasif pada sosial media memiliki efek yang paling signifikan terhadap komponen attention dari pada komponen sikap yang lain (Abdurrahim, Najib, \& Djohar, 2019).

Berdasarkan hasil data dan didukung oleh pendapat ahli diatas, maka dapat disimpulkan bahwa context pada pesan program Kota Kreatif memiliki hubungan dengan komponen attention terhadap pengembangan ekonomi kreatif. Hal ini menunjukan bahwa pesan yang dianggap penting dan relavan mampu memberi nilai tambah dimana followers menjadi ingin melihat dan ingin tahu mengenai informasi pengembangan ekonomi kreatif.

Koefisien korelasi sebesar 0,668 dengan kriteria 0,40 - <0,70 menunjukkan hubungan yang cukup berarti antara context (X1) dengan sikap interest (Y2). Hasil uji signifikansi diperoleh nilai $\mathrm{t}$ hitung sebesar 12,818 dan nilai $t$ tabel dengan $\alpha=5 \%$ dan $\mathrm{dk}$ (derajat kebebasan) $=\mathrm{n}-2=91$ adalah sebesar 1,986 maka dapat dilihat bahwa $\mathrm{t}$ hitung $(12,818)>\mathrm{t}$ tabel $(1,986)$ sehingga Ho ditolak. Dengan demikian dapat diambil keputusan bahwa terdapat hubungan yang signifikan antara context dengan komponen sikap interest.

Teori AISAS keputusan dibuat bergantung kepada sisi pesan yang digunakan dalam memproses sebuah keputusan. Jika individu mengolah pesanpesan persuasif yang diterimanya dengan semata-mata berfokus pada isi pesan, maka individu tersebut menggunakan context sebagai bahan pemrosesan pesan (Sugiyama, 2011). Komponen interest menyangkut masalah emosional subjektif seseorang terhadap suatu objek sikap. Secara umum, komponen ini disamakan dengan perasaan yang dimiliki terhadap sesuatu. Namun, pengertian perasaan pribadi sering kali sangat berbeda perwujudannya bila dikaitkan dengan sikap.

Komponen sikap interest adalah langkah setelah komunikator mampu untuk membuat sebuah media informasi menjadi media yang mengandung daya tarik bagi khalayak. Kebanyakan media informasi yang buruk melalaikan dalam melakukan tahapan ini, ditahap inilah sebenarnya target khalayak bersedia memberikan waktunya untuk membaca pesan dari pemasar lebih detail. Seharusnya komunikan dalam tahap ini membangun minat followers dengan memberikan janji atau harapan yang dapat diberikan kepada khalayak melalui context. Cara yang baik adalah dengan menjelaskan tahapan tata cara pelaksanaan dan benefit. Jangan hanya memberikan fakta dan fitur saja, dan merasa pembaca akan berpikir sendiri benefit yang akan di dapat, tetapi menjelaskan dengan sejelasnya benefitnya tersebut untuk meningkatkan interest (Sugiyama, 2011). Pada hal ini Dinas Komunikasi dan Informatika sudah cukup berhasil dalam 
menyajikan sebuah context pesan untuk membangun komponen sikap interest yaitu munculnya minat khalayak tertarik terhadap objek yang dikenalkan.

Hasil uji signifikansi diperoleh hitung sebesar 12,061 dan nilai t tabel dengan $\alpha=5 \%$ dan dk (derajat kebebasan) $=\mathrm{n}-2=91$ adalah sebesar 1,986 maka dapat dilihat bahwa $\mathrm{t}$ hitung $(12,061)>\mathrm{t}$ tabel $(1,986)$ sehingga Ho ditolak. Dengan demikian dapat diambil keputusan bahwa terdapat hubungan yang signifikan antara context dengan komponen sikap search. Koefisien korelasi sebesar 0,612 menunjukkan keeratan hubungan antara context dengan komponen sikap search merupakan hubungan yang cukup berarti.

Proses pencarian informasi ini berguna untuk peningkatan kepercayaan invidu terhadap pesan persuasi karena fakta dan data yang dikumpulkan oleh diri sendiri akan melekat sebagai keyakinan terhadap suatu hal. orang berperilaku dalam situasi tertentu dan terhadap stimulus tertentu akan banyak ditentukan oleh bagaimana kepercayaan terhadap stimulus tersebut. Pengertian kecenderungan berperilaku meliputi bentuk perilaku yang tidak hanya dapat dilihat secara langsung saja, tetapi meliputi pula bentuk-bentuk perilaku yang berupa pernyataan atau perkataan yang diucapkan oleh seseorang (Azwar, 2011).

Komponen sikap selanjutnya yang harus dibangun oleh komunikator melalui context ialah sikap khalayak untuk mencari informasi secara lebih mendalam mengenai topik yang sedang disajikan, di mana dalam komponen ini komunikator jeli atau pintar membaca target khalayak untuk memberikan stimulus agar memiliki rasa ingin tahu.
Komponen search untuk membuktikan bahwa komunikator mampu memberikan stimulus yang tepat yaitu context dalam membentuk sebuah keingin tahuan dan penggalian infromasi pada khalayak. Dalam tahap ini khalayak telah mempunyai motivasi untuk mencari informasi lebih dalam mengenai ekonomi kreatif. Sampai pada komponen ini, Dinas Komunikasi dan Informatika Kota Padang Panjang telah berhasil menciptakan rasa ingin tahu followers. Mayoritas followers sudah mulai goyah dan mencari tahu. Namun demikian timbul perlawanan dalam diri khalayak berupa keraguan, benarkah context yang bersangkutan memberikan sesuatu seperti yang dikatakan, maka dari itu khalayak mencari fakta dan data secara mandiri agar dapat memastikan kebenaran pesan persuasi. Hal ini diperkuat dengan hasil penelitian terdahulu yang menyatakan bahwa komunikasi persuasi pada sosial media saat ini menjadi lebih kompleks, dua level yaitu interpersonal dan komunikasi professional menjadi satu untuk mempersuasi khalayak agar mau tergugah dengan apa yang disajikan baik fakta maupun data (Watie, 2011).

Berdasarkan hasil di atas dapat ditarik kesimpulan bahwa context pada Program Kota Kreatif mampu mempengaruhi sikap pada komponen search para followers. Hasil penelitian tersebut menunjukan bahwa terdapat hubungan yang cukup berarti antara context terhadap komponen sikap search followers. Hal ini menunjukan bahwa pesan Program Kota Kreatif dalam akun Instagram dapat memancing respons khalayak untuk cenderung mencari dan mengumpulkan informasi mengenai pengembangan ekonomi kreatif meskipun 
belum semua peserta bersedia melakukannya.

Terdapat hubungan yang signifikan antara context dengan komponen sikap action. Koefisien korelasi sebesar 0,517 menunjukkan keeratan hubungan antara context dengan komponen sikap action merupakan hubungan yang cukup berarti. Dalam komponen yang paling pusat ini komunikator haruslah sudah berhasil mengarahkan khalayak pada tindakan untuk melakukan hal yang disampaikan melalui context. Dalam komponen action target melakukan keputusan untuk melakukan tindakan, tentunya sesuai dengan tujuan program yang telah ditetapkan. Dalam tindakan action ini yaitu yang salah satu upaya terakhir untuk membujuk khalayak agar sesegera mungkin melakukan tindakan bagian dari proses itu juga dengan memilih kata yang tepat agar target melakukan respons sesuai dengan yang diharapkan adalah suatu pekerjaan yang sangat sulit. Menurut penelitian terdahulu jika sudah sampai pada komponen action, maka isi pesan dan pengemasan pesan sudah mampu menciptakan kecenerungan berperilaku khalayak sesuai dengan tujuan (Ronauli, Wahyudin, Mustikasari, \& Mirawati, 2016). Maka dari itu jika mayoritas khalayak setuju untuk melakukan pengembangan ekonomi kreatif,Dinas Komunikasi dan Informatika telah berhasil menyiratkan perintah dalam context agar khalayak bertindak sesuai dengan apa yang diharapkan.

Suatu pesan persuasif dianggap relevan dan penting dikarenakan pesan tersebut berkaitan dengan nilai dasar atau dikarenakan pesan tersebut berkaitan dengan akibat yang tidak sepele (Azwar, 2011). Individu cenderung membagikan informasi yang berkaitan dengan dirinya, dan hal yang dianggapnya terhubung dengan nilai dasar kehidupan yang dianut, kemudian individu cenderung membicarakan hal yang memiliki sebab atau efek dengan dirinya. Pada context pesan Program Kota Kreatif, jika followers yakin bahwa pesan tersebut mengandung urgensi dan relevansi terhadap dirinya, maka followers akan membagikan informasi yang sudah mereka yakini memiliki kepentingan untuk diri mereka dan orang lain, meskipun tidak semua followers bersedia untuk melakukan share.

Dalam perkembangan media baru, media sosial termasuk kedalam media komunikasi dengan tingkat penyebaran informasi yang tinggi dengan alasan eksistensi diri pengguna media sosial (Aniswati, 2019). Jadi, ketika khalayak telah melakukan suatu tindakan maka akan besar kemungkinan mereka akan menyebarkan atau membagikan pengalaman tersebut sebagai hal positif dan peningkatan citra diri apabila melakukan hal yang baik. Kemudian, penyebaran pengalaman pribadi ini akan memiliki kekuatan untuk mempengaruhi pandangan pengguna lain mengenai hal yang dibagikan. Maka dari hasil jawaban responden mayoritas setuju untuk melakukan share, maka context pesan sudah mampu menstimulus khalayak membagi informasi sesuai dengan karakteristik sosial media sebagai media komunikasi yang sangat kuat dalam membagikan informasi atau pengalaman.

Kalangan remaja yang menjadi hiperaktif di media sosial untuk menunjukkan eksistensi diri, dan juga sering memposting kegiatan sehari-hari mereka yang seakan menggambarkan gaya hidup dan pengalaman mereka yang 
mencoba mengikuti perkembangan jaman, sehingga mereka dianggap lebih populer di lingkungannya (Akbar, 2019). Maka, apa pun yang dilakukan oleh khayalak akan dibagikan sebagai bukti eksistensi diri di media sosial, sebagai individu yang melakukan hal yang positif dan memiliki benefit, serta keinginan menginspirasi orang lain. Koefisien korelasi sebesar 0,571 menunjukkan keeratan hubungan antara content dengan komponen sikap interest merupakan hubungan yang cukup berarti. Penggunaan pesan hal - hal yang menggambarkan sesuatu secara visual juga mampu menarik perhatian khalayak. Pesan akan dapat mempunyai pengaruh yang besar untuk mengubah khalayak jika dikemas sesuai dengan kepercayaann yang ada pada diri khalayak jika dikemas sesuai dengan kepercayaan yang ada pada diri khalayak. Karenanya dari tujuan dan tema suatu program hendaknya dibuat pesan pesan yang sesuai dengan kepercayaan khalayak (Venus, 2009). Jadi, hendaknya content dari pesan persuasif disajikan agar menarik perhatian khalayak. Berdasarkan hasil penelitian, dapat disimpulkan bahwa content pada pesan mampu membuat khalayak tertarik atau pada komponen sikap interest.

Ketika khalayak sudah sampai kepada komponen sikap interest, hal tersebut bisa terjadi dikarenakan komunikasi melalu content sudah dapat dikatakan sempurna dalam menstimulasi khalayak. Kuncinya adalah bagaimana Dinas Komunikasi dan Informatika menyusun sebuah media komunikasi yang sesuai dengan tujuannya serta membangun content yang tepat, ketika khalayak melihat informasi. Content seharusnya juga merupakan bagian yang sangat baik untuk menciptakan khalayak menjadi bertambah interest terhadap program pengembangan ekonomi kreatif. Pengemasan yang dilakukan pada content pesan bukan hanya sebatas pada arti gambar seperti umumnya, namun menyangkut kepada semua petunjuk yang memberikan penjelasan tertentu pada isi pesan yang dikirimkan. Penggunaan ini mencakup juga penggunaan efek - efek suara dan efek grafis (Venus, 2009).

Pengemasan pesan mampu menimbulkan rasa ingin tahu yang besar dan menggali lebih dalam mengenai pesan yang disajikan. Hubungan yang berarti menunjukkan bahwa content telah membuat khalayak mencari dan mengumpulkan informasi mengenai program Kota Kreatif sebelum mempertimbangkan untuk melakukan tindakan walaupun belum semua dari followers melakukan tahap pencarian informasi.

Komponen sikap serach yang distimulus oleh content disebabkan oleh semakin berkembangnya teknologi komunikasi dan informasi yaitu internet yang sampai sejauh ini menciptakan era digital atau online. Search merupakan sebuah keuntungan bagi khalayak, karena dengan adanya mesin pencari, sebelum mengambil keputusan untuk melakuka tindakan, maka konsumen akan berusaha mencari informasi sebanyak-banyaknya melalui search engine dan semua informasi akan muncul dengan jelas di mesin pencari, inilah yang membantu khalayak untuk mengambil keputusan atas sebuah tindakan yang akan dilakukan.

Hubungan yang signifikan antara content dengan komponen sikap action. Koefisien korelasi sebesar 0,602 menunjukkan keeratan hubungan antara content dengan komponen sikap action 
merupakan hubungan yang cukup berarti. Hubungan yang cukup berarti ini menandakan bahwa penyampaian Program Kota Kreatif yang dikemas melalui keahlian tokoh, daya tarik tokoh, audio, dan visual berhasil dalam menimbulkan sikap untuk melakukan pengembangan ekonomi kreatif. Sehingga followers mengikuti pesan yang disampaikan oleh tokoh. Peran tokoh sangat penting untuk menyampaikan informasi, karena lebih dipercaya dan ditiru sikapnya oleh khalayak.

Hasil temuan Tetra Pak Index 2017 juga menunjukkan bahwa kemasan pesan (content) memiliki peran penting untuk menjadi pintu gerbang bagi keterlibatan khalayak yang lebih luas (Yudianto, 2019). Tindakan khalayak, disinilah the real experience tercipta. Proses interaksi pribadi antara khalayak dengan content yang disajikan oleh komunikator, kemampuan tokoh, daya tarik, audio, dan visualisasi merupakan satu kesatuan pengalaman yang benar-benar harus senantiasa dijaga semoga sesuai bahkan melebihi ekspektasi dari tindakan khalayak.

Jika dilihat hubungan content dengan komponen share followers terdapat hubungan yang cukup berarti. Berarti followers bersedia untuk membagikan informasi dan juga mengajak lingkungan sosialnya untuk melakukan pengembangan ekonomi kreatif. Hal ini dapat dilakukan secara langsung kepada lingkungan sekitar atau secara maya melalui jejaring sosial. Pada komponen ini, setelah melakukan pengembangan ekonomi kreatif maka khalayak akan berlanjut pada proses berbagi informasi (share) kepada orang orang di sekitarnya mengenai pengalaman atau gagasanya terhadap tindakan pengembangan ekonomi kreatif. Hal ini akan terjadi pada dunia nyata maupun online. Hal ini dibuktikan sejumlah responden telah mau untuk membagikan pengalaman mereka di sosial media mengenai pengembangan ekonomi kreatif yang telah mereka lakukan.

Dalam prinsip word of mouth (WOM) disebutkan bahwa sumber informasi yang bersifat personal akan dikenal, seperti teman, rekan kerja, dan kolega memiliki kecenderungan untuk diterima secara positif. Contoh sederhananya, khalayak akan lebih mempercayai rekomendasi dari orangorang yang dikenalnya. Komponen sikap share adalah hasil setelah konsumen merasakan semua pengalaman interaksi mereka dengan hal yang telah dilakukannya. mereka akan membagi pengalamannya kepada orang lain melalui email, chat, blogs, mailist, online forum, dan lain-lain. Sehingga pengalaman baik ataupun buruk akan mudah tersebar ke banyak orang melalui platform digital atau secara langsung.

Dengan demikian komponen sikap share pada Teori AISAS ini dapat menjadi tolak ukur keberhasilan komunikator untuk menstimulasi tindakan yang dilakukan khalayak dengan content sesuai dengan tujuan yang telah ditetapkan sebelumnya. Dapat dilihat dengan adanya hubungan yang cukup kuat antara share dan pesan.

\section{SIMPULAN}

Berdasarkan hasil penelitian, dapat disimpulkan bahwa terdapat hubungan yang kuat antara pesan Program Kota Kreatif pada akun Instagram @kominfopadangpanjang dengan sikap followers terhadap pengembangan ekonomi kreatif. Pesan program mengenai 
pentingnya melaksanakan pengembangan ekonomi kreatif yang disampaikan pada akun Instagram@kominfopadangpanjang sudah mampu mengubah sikap followers untuk mau melakukan pengembangan ekonomi kreatif meskipun masih terdapat kekurangan pada content dan context pesan, maka peneliti mengajukan beberapa saran, yaitu: Pada panduan ekonomi kreatif target dari Program Kota Kreatif didominasi oleh laki-laki dengan rentan usia 30-39 tahun. Di mana dalam program Kota Kreatif ini memperlihatkan bahwa pengusaha ekonomi kreatif dominasi pria pada usia matang. Padahal berdasarkan hasil penelitian ini, followers yang mengikuti program Kota Kreatif didominasi oleh banyak perempuan pada usia 20-29 tahun. Alangkah baiknya pesan dari kampanye ini lebih menyasar pada target wanita dengan usia muda 20-29 tahun saat ini yang menjadi pengusaha muda ekonomi kreatif. Kemudian berdasarkan hasil penelitian, sebagian besar followers akun @kominfopadangpanjang adalah mahasiswa, untuk itu perlunya penambahan pesan yang disajikan menggunakan tokoh influencer yang cukup dekat dengan kehidupan mahasiswa yang ingin mengembangkan usaha kreatif, Hal ini misalnya dengan menayangkan kisah inspiratif mahasiswa yang dapat mengembangkan usaha sambil berkuliah atau mengembangkan usaha dengan modal minim.

\section{UCAPAN TERIMA KASIH}

Ucapan terima kasih diberikan kepada seluruh pihak yang telah memberikan kesempatan, arahan dan masukan sehingga penelitian ini dapat diselesaikan. Tidak lupa pula terima kasih kepada pengelola dan reviewer Jurnal Avant Garde yang memberikan tanggapan positif, mendukung dan membantu peneliti menjadi lebih baik lagi sehingga memberikan semangat untuk melalukan penelitian selanjutnya.

\section{DAFTAR PUSTAKA}

Abdurrahim, M. S., Najib, M., \& Djohar, S. (2019). Development of AISAS Model to See The Effect of Tourism Destination in Social Media. Journal of Applied Management, 17(1), 134143.

Akbar, J. (2019, Desember 7). Dampak Media Sosial terhadap Perilaku Masyarakat. Retrieved from Kompas.com: https://www.kompasiana.com/jalalud inakbar9951/5b4753365e13734a6a5

3aea2/dampak-media-socialterhadap-perilakumasyarakat?page $=3$

Aniswati, S. (2019, Desember 7). Berkembangnya Media Sosial di Jaman Sekarang. Retrieved from Kompas.com:

https://www.kompasiana.com/siscaas niwati/596dcee $7 \mathrm{f} 7 \mathrm{afdd} 78457 \mathrm{c} 52 \mathrm{e} 2 / \mathrm{b}$ erkembangnya-media-sosial-dijaman-sekarang?page $=$ all

APJII. (2018). Asosiasi Penyelanggara Internet Indonesia. Retrieved from APJII: https://www.apjii.or.id/ Armstrong, P. a. (2001). Prinsip-Prinsip Pemasaran. Jakarta: Erlangga.

Azwar, S. (2011). Sikap Manusia Teori dan Pengkurannya. Jakarta: Pustaka Belajar.

Bryant, Z. (2015). Media Effect : Advances in Theory and Research. Eds, 91-117. 
Burhanuddin. (2015). Pengaruh Media

Sosial Twitter@Lowkerpku Terhadap Pemenuhan Kebutuhan Informasi Lowongan Kerja Bagi Followers. Jom FISIP, 2(2), 1-15.

Manisya, M. (2019). Penulusuran Kota Kreatif . Universitas Indonesia, 7-62. Munir. (2009). Pembelajaran Jarak Jauh Berbasis Teknologi Informasi dan Komunikasi. Bandung: Alfabeta.

Nida, F. L. (2014). Persuasi Dalam Media Komunikasi Massa. At-tabsyir, 2 (2), 77-95.

Prasetyo, H., \& Rachmawati, I. (2016). Analisis of AISAS on Asus Zenfone Users In Indonesia. e-Prociding of Management, 3(3), 27-65.

Putri, S. D., \& Ali, D. S. (2017). Pengaruh Online Campaign \#SamyangChallenge terhadap Consumer Behaviour Digital Natives Pengguna Youtube Indonesia. PRofesi Humas, 1(2), 132-141.

Rakhmat, J. (2005). Metode Penelitian Kuantitatif: Dilengkapi Contoh Analisis Statistik. . Bandung: PT. Remaja Rosdakarya.

Ronauli, M. P., Wahyudin, U., Mustikasari, F., \& Mirawati, I. (2016). Hubungan Antara Pesan Kampanye 9 Aksi Ramah Lingkungan Bandung Dengan Sikap Followers terhadap Gaya Hidup Ramah Lingkungan. Jurnal
Manajemen Komunikasi, 1(1), 125144.

Sugiyama, K. (2011). The Dentsu Way. United State: McGrow Hill.

Sugiyono. (2012). Metode Penelitian Kuantitatif, Kualitatif dan $R \& D$. Bandung: Alfabeta.

Sukmi, S. N. (2018). Thingking of Communication Theory on New Media Context. 3-53.

Sumbar, B. (2019). Sumbar Antara News. Retrieved from Sumbar Antara News.com:

https://sumbar.ataranews.com/berita/ 289452/menuju-kota-kreatif-duniawako-paparkan-padang-panjang-diajang-icf

Venus, A. (2009). Manajemen Kampanye; Panduan Teoritis dan praktis dalam Mengefektifkan kampanye Komunikasi. Bandung: Simbiosa Rekatama Media.

Watie, E. D. (2011). Communications and Social Media. The Messenger, 3(1), 69-74.

Yudianto. (2019), Desember 2019). Retrieved from Detik.com: https://inet.detik.com/cyberlife/d365 9956/132-juta-pengguna-internetindonesia-40-penggila-medsos 